\title{
Interactive Learning as Means of Formation of Future Teachers' Readiness for Self-Education
}

\author{
Elena V. Kondratenko ${ }^{1}$, Ilya B. Kondratenko ${ }^{1}$, Andrey V. Rybakov ${ }^{1}$, Valentina A. Svetlova ${ }^{1}$ \& Olga L. Shabalina ${ }^{1}$ \\ ${ }^{1}$ Mari State University, Yoshkar-Ola, Russia \\ Correspondence: Elena V. Kondratenko, Mari State University, Kremlevskaya Street 44, Yoshkar-Ola, Mari El, \\ 424002, Russia.
}

$\begin{array}{lc}\text { Received: February 21, } 2015 & \text { Accepted: March 15, } 2015 \quad \text { Online Published: April 29, } 2015 \\ \text { doi:10.5539/res.v7n8p35 } & \text { URL: http://dx.doi.org/10.5539/res.v7n8p35 }\end{array}$

\begin{abstract}
The problem under study is relevant due to an increased role of future teachers' self-education as a factor of his competitiveness and effective self-realization in the conditions of global paradigm of lifelong education and the necessity of designing educational technologies for formation of future teachers' readiness during his study at the university. The aim of the article is to study the effectiveness of interactive learning technologies in the practice of training future teachers as a means of forming their readiness for professional self-education. Main approaches to the study of this problem are the system and the activity approach, implemented in the process of formation of readiness of the future teachers for professional self-education at a modern university. Analysis of the results presented in this paper suggests that the use of the system application and methodically based combination of a variety of interactive learning technologies in the training of future teachers has a positive impact on the formation of all the components of readiness of future teachers for professional self-education (motivational, value, cognitive, activity, reflexive). The article may be useful for university teachers implementing training of future teachers.
\end{abstract}

Keywords: professional self-education, readiness for self-education, interactive education, interactive learning technology, training teachers

\section{Introduction}

The dynamic development of modern society, the emergence of new technologies, the expansion of the flow of information calls for self-improvement and lifelong self-education. In this regard, the problem of formation of readiness updated to independent professionals meets their educational needs through their own social mobility and creative activity in continuous updating of a professional activity. Formation of readiness for self-education of a future teacher has its own specificity, which is determined as the need of a modern teacher to acquire a combination of significant skills and experience of their implementation: the ability to work with different sources of information, knowledge of the fundamentals of the scientific organization of pedagogical work; the ability to analyze, compare, set the relationship between pedagogical phenomena and processes, ability to listen and speak, to defend his point of view, the ability to work in a team, resolve conflicts, to adapt to changing conditions, be psychologically stable to difficulties; design programs and projects of their professional activities, to take responsibility, to be able to organize their own work, to simulate the professional activity, and so on (Kondratenko, 2012).

Formation of these future teachers' abilities is not possible without taking part in an active cognitive activity, creating a variety of situations of pedagogical interaction in the process of training, turning them into a genuine subject of the process (Rybakov, 2014). In this regard, interactive learning is of particular importance in the process of training future teachers, carried out in various forms of joint activities of students, in which all participants of the educational process interact with each other, engaging in business cooperation to resolve the educational and professional problems, sharing information, simulating the situations of communication, assessing the actions of other participants and their own behavior.

The concept of "interaction" was first used to describe the social interaction in sociology and social psychology in the first third of the twentieth century in the framework of symbolic interactionism. This theory is characterized by the consideration of interactions as social interaction of people, defining personal development, creation of a person's "self". Later interaction problems have been considered in the works of such foreign 
scientists as John Chiari, M. L. Nuzzo, J. Raskin and others. In Russia, the notion of "social interaction" was used within the framework of social constructivism; its foundations were laid by Vygotsky. In modern psychology "interaction" is defined as the ability to interact or be in the mode of a dialogue with anyone (anything) and refers to the interaction and mutual influence of individuals or groups on each other, based on a dialogue (Kondratenko, 2014).

Pedagogical interaction in the process of interactive learning is a significant factor in the formation of such personal qualities as subjectivity (K. A. Abulkhanova-Slavskaya, A. N. Leontiev, S. L. Rubinshteyn). In Russian psychology, starting with Rubinshtein (1973), subjectivity is associated with the implementation of a person's own choice, the presence of clearly defined objectives, with the demonstration of ambitions in planning and constructing his own life. According to K. A. Abulkhanova Slavskaya (1980) a person as a coordinator of an activity is primarily characterized by the ability of self-regulation, which in turn allows updating the mental processes that regulate his state according to the tasks and events of an activity. In the process of becoming a subject a person acquires new qualities, masters the appropriate knowledge, skills, definite professional standard methods of work.

One of the manifestations of the subjectivity of a person of a future teacher, formed in the process of pedagogical interaction, is his readiness for professional self-education.

Most researchers Charles D. Hayes, K. Gessler, L. Klingberg, K. L. Klauer, R. Simpson, Bink, Davis (The USA), X. Shane, W. Ofals, L. Haymovitts (France), K. Osuik, G. Kay, J. Annette, L. Reid, G. Pasek (England), L. Iacocca (Japan) treat self-education as activities related to self-organization, which involves the development of the individual's ability to formulate independently and realize the purpose and objectives of activities, to choose appropriate means of achieving them, exercise self-control, self-analyses, self-reflection. Therefore, the main characteristics of self-education can be distinguished as its personalized character, consciousness, purpose and systematic nature.

In this regard, the readiness of a teacher to self-education can be defined as an integrated dynamic property of a person, reflecting the unity and interrelation of the cognitive, motivational and practical readiness for the active self-educational work on the basis of a valuable attitude to teaching and the desire for self-realization in it.

Survey of the works on the problem of and summary of experience in organizing pedagogical education at the university suggests that the use of interactive learning technologies in the process of training future teachers will contribute to formation of their readiness for professional self-education.

\section{Materials and Methods}

To achieve the goal of the research and to confirm the validity of the hypothesis it is necessary to solve the following problems:

1) To define the essence of readiness of future teachers for professional self-education;

2) To reveal the contents of interactive learning in the context of professional training of future teachers for professional self-education;

3) To identify and verify experimentally pedagogical conditions of formation of readiness of future teachers for professional self-education in the process of interactive learning.

Methods of research, contributing to the solution of the problems are: the survey of psychological and pedagogical literature and regulatory documents on the problem; questionnaires methods (an interview, questionnaires, tests); SWOT-analysis; observation; modeling; pedagogical experiment; mathematical methods and statistical processing of the results of the experimental research. In the statistical analysis for determining the validity of the obtained results paired Student's t-test was used.

The first stage of the research was connected with the analysis and theoretical reasoning of the problem, the formation of the goals and objectives of the study, the research hypotheses and designing tools to prove it, carrying out an ascertaining experiment. The second stage was aimed at experimental verification of the influence of the pedagogical conditions on the efficiency of formation of readiness of future teachers for professional self-education. The third stage was devoted to summarizing the experiment and included theoretical comprehension, quantitative and qualitative analysis, synthesis and description of the results of experimental work and the research as a whole.

Experimental research base is a federal state educational institution of higher professional education "Mari State University." In the experiment 156 students and 52 lecturers took part.The experimental group consisted of 76 students of the Institute of Pedagogy and Psychology. The control group consisted of 80 students of the Faculty 
of Physical Culture, Sports and Tourism. Randomization of experimental and control groups was carried out taking into account the area of training ("Teacher Training Education"), age of students (19-21 years), the similarity of profiles of training (future teachers of humanitarian subjects).

\section{Results}

At the first stage of the experiment the following problems were solved: clarification of the real state of the use of interactive learning technologies in the process of training future teachers at the university; identifying the indicators of levels of formed-readiness of the future teachers to self-education; selection of methods for diagnosing the level of readiness of the future teachers to self-education in the process of interactive learning; conducting research ascertaining the level of formation of readiness of the future teachers for self-education; preparation of the curriculum of the special course "Self-development of the person of a teacher."

At the stage of ascertaining experiment, we developed an original questionnaire for assessing the level of organization of interactive learning at the university. 156 students and 52 lecturers were interviewed.

Based on the fact that the concept of interactive learning is unknown to all students they were asked to identify the most common types of pedagogical interaction used in the practice of their professional training in high school, and to evaluate their effectiveness. As the predominant types of pedagogical interaction the students were given "a student-a teacher" ( $40 \%$ of students) and "a group of students-a teacher" ( $40 \%$ of students). Such types of pedagogical interaction as "a student - a group of students" and "a student - electronic learning resources" were marked as the most wide-spread by $10 \%$ of the students. Pedagogical interaction "a student-a teacher" was marked as the most effective (55.3\% of students), $31.6 \%$ of respondents chose "a group of students - teacher" as the preferred type of interaction, $21.1 \%$ - "student—electronic learning resources". In our opinion, the low estimation of the efficiency of interaction "a student - a group of students" is caused by the fact that this type of interaction is not widely used in the practice of professional training at the university. This assumption is confirmed by the analysis of the results of the students' answers to the question "Which of the following forms and methods are used in the course of your professional education?": $42.1 \%$ of students identified group discussions, $23.7 \%$ - project technologies, $21 \%$ - mutual learning technology, role and business plays, $13.2 \%$ - technologies of case-study, which are based on such type of pedagogical interaction as "a student-a group of students."

52 lecturers took part in the questionnaire. Of these, 34.6\%-lecturers of Humanities, Social and Economic Sciences, $7.7 \%$ - lecturers of Mathematics and Science, $57.7 \%$ - teach disciplines of professional training.

Analysis of the results of the questionnaire survey of lecturers revealed that most of them $(80.8 \%)$ correctly define the essence of interactive learning as learning, built on students' educational interaction with teachers, students, electronic learning resources. Only $7.7 \%$ of respondents define interactive learning as learning organized with the necessary use of electronic learning resources. $11.5 \%$ of lecturers pointed out the main characteristics of interactive learning as its focus on the formation of students' practical work experience, rather than fundamental theoretical knowledge. The lecturers defined such essential characteristics of interactive learning as a feedback between teachers and students; use of electronic learning resources and IT in the process of training; account of personal experience of students; activation in cognitive activity of students; intensive process of communication, organization of educational interaction between students; focus on the development of professional competences; involving students in active self-education activity; use of professionally-oriented learning technologies; creating conditions for student with various sources of information; self-assessment of students results.

The lecturers placed emphasis on such interactive learning technologies as group-discussion (92.3\%), IT (61.5\%), technology of solutions of professional tasks $(53.8 \%)$, problem lectures $(46.2 \%)$, technology of e-learning $(46.2 \%)$. To a lesser extent such technologies as project technology, case-study, lecture with mistakes (provocation), games, debates and others are used.

Despite the fact that most of the lecturers (92.3\%) admit necessity to use interactive learning technologies, $63.5 \%$ admit that they have difficulties in using them. The main difficulty for most of the them is the lack of methodological knowledge in the field of interactive learning (55.8\%); lack of time to prepare and organize activities with the use of interactive learning technologies (40.4\%); inappropriate level of equipment with interactive learning tools (34.6\%); low level of motivation of students to independent cognitive activity (26.9\%); low level of readiness of students to interaction in the learning process $(21.2 \%)$.

SWOT-analysis was held on the basis of the survey results of students and lecturers' questionnaire which showed that the positive trends can be traced in the use of interactive technologies. The majority of students and lecturers 
evaluate the true range of goals and objectives of the training to be solved by means of interactive learning. It should be noted that in the process of training of future teachers at the University there are problems of using interactive learning technologies, as such types of pedagogical interaction as "a student-a group of students", "a student - electronic educational resources" are not used enough and the predominant forms of organization of the process of training at the University are still the traditional seminars and lectures. One of the solutions to these problems is the development of information learning environment of the University. In addition, the prospect of the development of interactive learning at the university is expanding the range of types, technologies and means of interactive learning in the process of training of future teachers. However, there is a risk of non-compliance with the Federal state educational standards for professional training of future teachers and the level of professional competence.

Formation of readiness of the future teachers for professional self-education is carried out within the invariant and variable components of training. Invariant content of training were disciplines of professional cycle ("Pedagogy", "Psychology"), variability was presented in the experimental group with the course "Self-development of the person of a teacher."

Interactive learning technologies have been used for all stages of the process of training of future teachers.

At the stage of learning new material such forms of learning as problem lectures, lecture-visualization, lecture - press conference, lecture-provocation were used. For example, in the study of the topic "The system of continuing pedagogical education" within the course "Pedagogy" course the material was offered to students in the form of a problem lecture. The structure of a problem lecture suggests that new knowledge is introduced in the process of resolving the situation in cooperation and dialogue with the students by organizing the search for the solution. Problem building of lectures contribute to the students' adoption of goals of teaching and learning activities, their involvement in active research, so it solves the problem of the formation of the cognitive component of readiness of the future teachers to self-education. Therefore, while designing and organizing of a problem lecture we sought to take into account the level of cognitive activity of students, did not impose our own vision of the problem, rather than presenting it as one of the solutions, but analyzed all the options of the solution, proposed by students. At the beginning of the lecture the students were given three problematic questions: "What is manifested and ensures the continuity of teacher education?", "What are the main steps in continuing teacher education? What are their main characteristics?" "What is the relationship between a continuous pedagogical education and self-education of a teacher?" Answers to these questions were discussed during the panel discussion at the end of class; the results of the discussion were visualized by each student in a cluster "I am in the system of continuing education."

Formation of the cognitive component of readiness of the future teachers to self-education is implemented by using lectures - press conferences, in the preparation and conduct of which involves the students themselves, acting as experts in a particular pedagogical problem. After a brief talk about the nature of a particular pedagogical problem and ways of solution students experts respond to specifying questions of other students. The necessity to formulate a question and ask it correctly activates students mental activity, and waiting for an answer to their questions concentrates their attention to the material. Questions from students in most cases have problematic nature and start creative thinking processes.

At the stage of summarizing, reviewing and systematization of knowledge of students such technology were used as technology of solving professional tasks, the project technology, and case-study. Technology of case-study was used to review and summarize knowledge on "Methodology and methods of research". Future teachers solved mini-case tasks connected with the use of different technoques of pedagogical research in the course of professional activities. There were several stages in considering the situation:

1) Analysis of the practical situation in the subgroup as a stage of independent work of students, which allowed each student to participate in discussions, express their views and insight into the views of other participants, which helps to develop skills of teamwork. The main task of the subgroups at this stage was to prepare for the formulation of its conclusions to the intergroup discussion;

2) Preliminary discussion of the situation in the classroom, during which the teacher answered the questions asked by the participants of the analysis;

3) Intergroup discussion, during which representatives delegated by each of the subgroups for the presentation of the final material, presented the results of their analysis and their suggested solutions, and participants from other subgroups acted as opponents. The teacher played the role of a coordinator and a leader of the discussion and, if necessary - the opponent and critic, activating and directing the discussion; 
4) Summary was carried out not only be the teacher who evaluated the conclusions of subgroups and individual participants, as well as the course of the discussion, but also the participants themselves, thereby forming their capacity for reflection-evaluation activities.

This technology is most effective for the formation of the activity and reflexive components of readiness of the future teachers for professional self-education as it successfully generates meta-competences associated with the formation of the ability to define the scope of the additional information necessary to clarify the initial situation, to use a variety of approaches to develop an action plan aimed at achieving the final outcome; to develop the ability to carry out the presentation, i.e. convincingly present, justify and defend their point of view; develop the skills of constructive critical evaluation of alternative points of view; to develop the ability to make their own decisions based on the group analysis of the situation; to acquire practical experience and to provide feedback (Shabalina, 2011).

At a seminar on "Professional and personal qualities of a modern teacher" there was the defense of group research projects of students A Perfect Teacher: Who is he?" "Professional pedagogical culture of a modern teacher and its characteristics", "Styles of pedagogical activity".

Project technology is combined with the group (cooperative learning) approach to teaching, which is widely used in modern education. There are several reasons of not only pedagogical but mostly social background:

- The need not to transfer to students a certain amount of knowledge but to teach them to acquire the knowledge themselves, to be able to use the acquired knowledge to solve new cognitive and practical problems;

- Relevance of the acquisition of communicative skills, i.e. skills to work in different groups, performing different social roles (a leader, an artist, an opponent);

- Relevance of the broad human contacts, leaning different cultures, different points of view on the issue;

- Significance for a future teacher of the ability to use research methods: get the necessary information, the facts; be able to analyze them from different points of view, formulate hypotheses, and draw conclusions.

From the point of view of solving the problems of formation of readiness of future teachers to self-education, project technology is primarily focused on the formation of communicative activity competences in the field of social interaction (the ability to cooperate in learning activities, take and give help, design and coordinate the process, plan activities, distribute responsibilities for a group project, take decisions); information competencies (readiness to independently search for the information, determine what information or skills lack for the task); reflexive competence (the ability to critically evaluate the results of the their own and other activities, gained through project work experience, choose their role in the collective activity).

An important condition for the formation of the future teacher readiness for self-education is IT (Selwyn \& Gorard, 2006). A special role in their implementation was assigned to the system of e-learning LMS Moodle.

Analyzing the didactic possibilities of Moodle for organization of interactive learning, presented in Table 1 some attention should be paid to the characteristics of the elements of Moodle, providing pedagogical interaction in the process of interactive learning (forum, chat, glossary, Wiki, workbook).

Table 1. Didactic possible elements of Moodle in the implementation of interactive learning technologies

\begin{tabular}{|c|c|c|c|}
\hline \multicolumn{2}{|c|}{ Stages of learning } & Interactive learning technologies & \multirow[t]{2}{*}{ Moodle Tools } \\
\hline $\begin{array}{l}\text { Learning } \\
\text { material }\end{array}$ & new & $\begin{array}{ll}\text { Lectures } & \text { (lecture-visualization, } \\
\text { lecture-provocation) } & \end{array}$ & \\
\hline & & lecture - press conference, lecture-consultation & Forum, test \\
\hline \multirow[t]{3}{*}{ Review } & & Group discussions, seminars & Forum, chat, seminar \\
\hline & & Projecttechnologies, practicetasks & $\begin{array}{l}\text { Tasks, Wiki, forum, portfolio, } \\
\text { chat }\end{array}$ \\
\hline & & $\begin{array}{l}\text { Technologies of organizing independent work } \\
\text { case-study }\end{array}$ & $\begin{array}{l}\text { Glossary, forum, portfolio, tasks } \\
\text { Wiki, forum, portfolio, chat }\end{array}$ \\
\hline \multirow{2}{*}{\multicolumn{2}{|c|}{ Control }} & Technologies of organizing independent work & $\begin{array}{l}\text { Test, tasks, portfolio, essayTecт, } \\
\text { задания, портфолио, эссе }\end{array}$ \\
\hline & & Test technology & Test \\
\hline Reflection & & $\begin{array}{l}\text { Technology of assessment and self-assessment of } \\
\text { learning }\end{array}$ & Questionnaire \\
\hline
\end{tabular}




\section{Discussions}

Analysis of the results of international research in the field of quality assessment of education, particularly monitoring research program "Education for all throughout life"; reports and recommendations developed by the International Bureau of Education and the International Institute for Educational Planning, UNESCO Institute for Education and Information Technologies in Education, UNESCO Institute of Statistics reports "Education at a Glance", as well as analysis of the OECD "Indicators of Education Systems" (INES-Indicators of Education Systems) suggest that the achievement of high educational outcomes is provided, first of all, by the organization of training activities implemented by using innovative forms, means and methods of teaching and learning technologies aimed at forming a subject position of the student.

In this context, the need for the use of interactive learning technologies based on the theory of symbolic interactionism (J. G. Mid (USA), G. Blumer (USA), D. M. Bolduin (USA), Ch. Kuli (USA) and others) in the training system of a modern teacher is determined by the transition from training to learning. The priority is shifted to technologies of organization of independent activities of future teachers in order to develop the content of the profession - the technology of independent work, technology module-rating training.

In the works of I. G. Abramova, N. P. Anikeeva, A. A. Verbitsky, V. V. Guzeeva, V. K. Dyachenko the problems of development and use of interactive teaching methods are discussed. Currently, the concept of "interactive teaching methods" are filled with new content, the priority role in it is given to interaction (M. V. Klarin, G. K. Selevko, G. I. Chemodanova); development and implementation of the social experience of people (L. N. Kulikova); teaching and learning cooperation between the participants of the educational process (S. S. Kashlev, E. V. Korotaeva, N. E. Schurkova and others).

The use of interactive learning technologies in the process of teacher training assumes the decision of educational and professional tasks that require independent thinking, understanding of knowledge gained in the course of training, analysis of pedagogical phenomena and facts, planning their own activities and relate its objectives, content and results with those of other subjects of teaching interaction, development of creative skills, research skills, identification of ways of professional self-development.

The idea of readiness for self-education, so relevant today, found its reflection and development in the historical heritage of Russian pedagogy. The following key aspects are found there: the inextricable interrelation and interdependence of the processes of education and self-education (K. D. Ushinsky, Leo Tolstoy); nomination of ideal of a thinking personality, capable of self-knowledge and self-organization (D. I. Pisarev, V. Y. Stoyunina); training demands for self-education and self-improvement (N. I. Kareev, P. F. Kapterev); the need to form skills of self-activity (D. I. Tikhomirov); the effectiveness of independent work as a means of self-education (N. K. Krupskaya, M. N. Skatkin); creative nature of self-educational activity (V. A. Sukhomlinsky); the role of the teacher in shaping the readiness for self-education (D. D. Semenov, K. P. Yanovsky) (Shabalina \& Svetlova, 2014).

In modern scientific literature, the term "self-education", its theoretical status and specificity, in our opinion, are not uniquely defined: as the direction of self-education (V. V. Bondarevskaya, A. G. Kovalev, B. F. Raysky); as purposeful cognitive activity (A. K. Gromtseva, L. G. Kovtun); as a means of assimilation of social experience (T. A. Ilyin, G. N. Serikov); as a vital priority (R. G. Brockett, S. Brookfield, P. C. Candy, M. Knowles) (Candy, 1991; Hiemstra \& Brockett, 2012; Knowles, 1975).

\section{Conclusion}

Readiness of the teacher for self-education acts as an integral dynamic property of the person, reflecting the unity and interrelation of cognitive, motivational, and practical readiness for active self-educational activity on the basis of the valuable relation to teaching and the desire for self-fulfillment in it.

As structural components of readiness of the teacher's personality for self-education we have identified the following:

- A cognitive component comprising ideas and concepts about the nature, methods and forms of self-education, structure, characteristics, conditions of pedagogical activity;

- A motivational component represents the system of goals, objectives, needs and motives of self-education;

- An activity component that reflects the mastery of techniques and operations of self-educational activities, methods of search, selection and processing of information;

- A reflexive component for self-examination of the situation of professional development, self-esteem of personal and professional qualities and competencies, self-regulation of the process of improvement (Svetlova, 
2013).

All components of the readiness of the teacher for self-education are closely connected and formed throughout a person's life, but the most favorable period to form the basis of future teacher readiness for self-education is a period of training at the university. Interactive learning is of particular importance in the process of training future teachers as it is carried out in various forms of joint activities of students, in which all participants of the educational process interact with each other, engaging in cooperation to resolve the educational and professional problems, sharing information, simulating the situation of communication, evaluating the actions of other participants and their own behavior.

Results of the research prove that the use of interactive learning technologies in the training of future teachers has a significant influence on the formation of their readiness for professional self-education. In particular, the process of the formation of the cognitive component of the readiness of the future teachers for professional self-education is most effective with the use of such interactive learning technologies as problem lectures, lecture-provocation, binary lecture, lecture-consultation, seminar-discussion aimed at forming critical thinking, comprehensive and systematic vision of the problem. Motivational component of readiness for professional self-education involves identifying the range of interests and needs of students, the attitude to self-education, self-activation of the cognitive activity of the students, the formation of a creative, constructive and active setting for their future profession in the use of such interactive learning technologies as technology of situational training, case study method, lecture-press conference, problem lectures and others.As a result of the use of such interactive learning technologies as the technology of organization of games and project activities, information and communication technology, and the involving students in active research and educational actions in the organization of teaching interactions the ability of future teachers to act independently and to make appropriate decisions in various situations, including those relating to professional self-education is formed, which determines the success of the formation of the activity component. In the context of the implementation of such interactive learning technologies as game technologies, solution of professional tasks, group discussions, lectures-provocations the reflective component of the readiness of future teachers for professional self-education is formed, which involves self-examination of the situation of professional development, self-esteem of personal and professional qualities and competencies, self-regulation process of improvement.

\section{References}

Albukhanova-Slavskaya, K. A. (1980). Activity and psychology of personality. Moscow: Nauka.

Candy, P. C. (1991). Self-Direction for Lifelong Learning: A Comprehensive Guide to Theory and Practice. San Francisco: Jossey-Bass Publishers.

Garrison, D. R. (1997). Self-Directed learning: Toward a comprehensive model. Adult Education Quarterly, 48(1), 18-33. http://dx.doi.org/10.1177/074171369704800103

Grow, G. O. (1991). Teaching Learners to be Self-Directed. Adult Education Quarterly, 41(3), 125-149. http://dx.doi.org/10.1177/0001848191041003001

Hiemstra, R., \& Brockett, R. (2012). Reframing the Meaning of Self-Directed Learning: An Updated Model Retrieved September 20, 2013, from http://www.adulterc.org/Proceedings/2012/papers/hiemstra.pdf

Knowles, M. S. (1975). Self-directed learning: A guide for learners and teachers (p. 135). Englewood Cliffs: Prentice Hall Cambridge.

Kondratenko, E. V. (2012). Technology of professionally oriented learning in higher education (p. 280). Yoshkar-Ola, MarSU.

Kondratenko, I. B. (2014). Interactive learning technology as a factor of formation of readiness of the future teachers to the profession. Humanitarian, social, economic, and social sciences. Retrieved from http://www.online-science.ru/m/products/pedagogical_sciense/gid1710/pg0

Rubinshtein, S. L. (1973). Problems of Psychology. Moscow: Prosveschenie.

Rybakov, A. V. (2014). Criteria of readiness of the future teacher to patriotic education of pupils by means of local lore work—Kazan Science (pp. 241-243). Kazan: Kazan Publishing House.

Selwyn, N., \& Gorard, S. (2006). Adults' use of computers and the Internet for self-education. Studies in the Education of Adults, 2, 141-159.

Shabalina, O. L., \& Svetlova, V. A. (2014). The idea of formation of readiness of the individual to self-education in retrospect domestic pedagogical thoughts. Bulletin of the Chuvash State University, 1, 170-173. 
Shabalina, O. L. (2011). Modern methodological approaches to teacher preparation. In Teacher training in the modernization of higher education: The collective monograph. Mari state University, Yoshkar-Ola.

Svetlova, V. A. (2013). Formation of readiness of the individual teacher to educate themselves as a scientific problem. Modern problems of science and education, 4. Retrieved from http://www.science-education.ru/110-9929

\section{Copyrights}

Copyright for this article is retained by the author(s), with first publication rights granted to the journal.

This is an open-access article distributed under the terms and conditions of the Creative Commons Attribution license (http://creativecommons.org/licenses/by/3.0/). 